\title{
Predominant Expression of Circulating CD3+ Lymphocytes Bearing Gamma T Cell Receptor in a Prolonged Immunodeficiency after Allogeneic Bone Marrow Transplantation
}

\author{
Etienne Vilmer,"* Paul Guglielmi, Violaine David, Gérald Leca, Claire Rabian," Laurent Degos," \\ Michel Boiron," and Armand Bensussan ${ }^{\star}$ \\ *Unité de greffe de moëlle, Département d'Hématologie, Hôpital Saint Louis, Paris, France; ${ }^{\ddagger}$ Institut National de la Santé et \\ Recherche Medicale (INSERM) U 93, Immunogénétique de la Transplantation and INSERM U 108, Hôpital Saint Louis, \\ ${ }^{\S}$ INSERM U 23 Hôpital Saint-Antoine, Paris, France; "Laboratoire d'Immunologie, Hôpital Saint Louis, Paris, France
}

\begin{abstract}
The cell surface expression of $\alpha: \beta$ heterodimer was studied using WT31 monoclonal antibody, in peripheral blood lymphocytes (PBL) from a patient who developed a prolonged immunodeficiency after allogeneic bone marrow transplantation. This patient, grafted for chronic myelogenous leukemia, received $T$ cell depleted bone marrow from her HLA, A, B, D matched sibling. The late occurrence of opportunistic infection, led us to analyze the phenotype of patient PBL. 70\% of PBL were CD3+ and 29\% WT31+, indicating that the majority of CD3+ PBL did not express the $\alpha: \beta$ heterodimer. Transcription of the genes encoding the $\alpha, \beta$, and $\gamma$ chains was assessed in cell lines derived from PBL, by Northern blot analysis. We showed that the CD3 + WT31 - subset expressed a truncated, $\beta$ mRNA (1.0 kb) and also truncated $\alpha$ transcript $(1.4 \mathrm{~kb})$. To determine the CD3-associated structure on CD3 + WT31- cell line, immunoprecipitation assays were performed using monoclonal anti-CD3 and an hetero antiserum against $\gamma$ peptides. These CD3 + WT31 - cells expressed a disulfide linked dimer, composed of products of $\gamma$ gene $(37 \mathrm{kD}, 40 \mathrm{kD})$ and of undefined $\delta$ chain $(45 \mathrm{kD})$. Functional analyses were performed in PBL before and after sorting with WT31 and anti-CD3 antibody. These circulating CD3 + WT31-cells were unable to proliferate when triggered with anti-T3 beads and they seemed to mediate a suppressor activity on CD3 + WT31 + cells.
\end{abstract}

\section{Introduction}

Two different $\mathrm{T}$ cell receptors (TCR) ${ }^{1}$ have so far been identified, the $\alpha: \beta$ heterodimer expressed on CD4 and CD8 cells and a recently described dimer composed of products of $\gamma$ gene and $\delta$ chain $(1-11)$. Both dimers are independently expressed on the cell surface of distinct subsets of $\mathrm{T}$ cells, in association with the CD3 (T3) complex. Recent studies of the ontogeny of TCR/CD3 complex have shown that $\gamma: \delta$ dimer is first de-

Address reprint requests to Dr. Vilmer, Unité INSERM 93, Hôpital Saint Louis, 1, Av Claude Vellefaux, 75475 Paris, Cedex 10 France.

Received for publication 28 March 1987 and in revised form 16 December 1987.

1. Abbreviations used in this paper: BMT, bone marrow transplantation; CMV, cytomegalovirus; GVHD, graft versus host disease; TCR, $T$ cell receptor.

J. Clin. Invest.

(C) The American Society for Clinical Investigation, Inc.

0021-9738/88/09/0755/07 \$2.00

Volume 82, September 1988, 755-761 tected, $\sim 2 \mathrm{~d}$ before the cell surface expression of $\alpha: \beta$ heterodimer $(12,13)$ but it is not yet clear whether cells expressing $\gamma$ chains require thymus processing. These TCR $\gamma: \delta$ cells, which were mainly double negative, CD4-CD8-, represent a minor subset, about $6 \%$ of normal adult peripheral blood lymphocytes $(\mathrm{PBL})(10,14)$. They have been isolated and characterized from fetal blood (1) from the leukemia cell line termed PEER (4) and from the cell lines established from PBL of two patients with congenital immunodeficiency (3).

In the setting of allogeneic bone marrow transplantation (BMT), the differentiation of immature donor T lymphocytes is required to achieve functional immune reconstitution. $\mathrm{Ab}$ normal differentiation of donor $\mathrm{T}$ cells in the recipient is thus to be expected since the immunodeficient state persisted several months after grafting (15). Consequently, we have sought to analyze the surface expression of two distinct TCRs in PBL from grafted patients. (MAb) termed WT31, which reacts with a nonpolymorphic determinant expressed on $\alpha: \beta$ heterodimer may be used to identify $T$ lymphocytes that do or do not express $\alpha: \beta$ chains (16).

Interestingly, a predominant circulating subset of $\mathrm{CD} 3+$ WT 31 - cells was detected in one of our patients who received $\mathrm{T}$ cell-depleted bone marrow from her HLA matched donor. The characteristics of CD3 associated structure was studied in these CD3 + WT $31-$ cells that did not transcribe functional $\alpha$ and $\beta$ mRNA. We showed that a disulfide linked dimer composed of $\gamma$ and $\delta$ chains was expressed on the cell surface of this subset. Functional analysis was performed in patient PBL before and after sorting with WT31 and anti-CD3 MAb; a relationship between the in vivo expansion of these TCR $\gamma: \delta$ bearing cells and the immunodeficient state was shown.

\section{Methods}

\section{Patient}

In August 1985, a 23-yr-old female was grafted for Philadelphia positive chronic myelogenous leukemia in an accelerated phase. Details of the BMT procedure and supportive care have been published elsewhere $(17,18)$. The pretransplant conditioning regimen consisted of Belustine, $100 \mathrm{mg} / \mathrm{m}^{2}$; cyclophosphamide, $120 \mathrm{mg} / \mathrm{kg}$ and total body irradiation (a single dose of $10 \mathrm{~Gy}$ ). The donor was a class-I and -II HLA compatible brother. In vitro depletion of $T$ lymphocytes from donor marrow was achieved with a cocktail of three murine MAbs (anti-CD2, CD5, and anti CD7) plus baby rabbit complement-mediated lysis. The donor $\mathrm{T}$ cell-depleted marrow was evaluated for residual $\mathrm{T}$ lymphocytes by a limiting dilution assay that determined the frequency of PHA IL-2 responsive T lymphocytes, according to the method already described (19). Total residual clonable T lymphocytes, infused to the recipient, was estimated at $4.10^{6}$ cells $/ \mathrm{kg}$. Hematological 
reconstitution was observed within 6 wk postgrafting. Cytogenetic analysis showed the complete disappearance of Philadelphia chromosome and the exclusive presence of donor hematopoietic cells, $6 \mathrm{mo}$ after BMT. As prophylaxis of graft versus host disease (GVHD), cyclosporine A was given according to our protocol (17) and was associated with methotrexate (days $1,3,6,11$ ). On day 86 , the patient developed mild GVHD grade 1 proven by skin biopsy, treated with a course of steroids. Cyclosporine A was stopped 6 mo postgrafting. A limited chronic GVHD occurring 1 yr after BMT, was treated with 6-mercaptopurin and steroids.

Disseminated and prolonged cytomegalovirus (CMV) infection occurred from week 7 until the week 24, characterized by the repeated isolation of CMV from blood, and by the late development of severe CMV retinitis and uveitis in week 24 postgrafting. This unusual complication was associated with important lesions of vascularitis responsible for the occurrence of blindness despite several courses of ganciclovir (9-[2-hydroxy-1-(hydroxymethyl) ethoxymethyl] guanine) (20). Such late infection evoked a persistent immunodeficient state of which the cause was not apparent: the patient no longer had GVHD. HIV serology was negative.

As of week 7 after graft, an absolute increase of lymphocytes $(5,000-10,000 / \mu \mathrm{l})$ with normal morphology was noted and persisted throughout the 16-mo followup. A steady increase of serum globulin (25-35 g/liter) associated with monoclonal IgG component was also observed. Immunological tests performed in the first, third, sixth, and ninth months after BMT showed 70\% CD3+ lymphocytes and the complete absence of proliferative response to mitogens (PHA, pokeweed, and concanavalin A) and to antigens (candidin, varidase, and $\mathrm{CMV}$ ).

\section{Cell preparation and functional assays}

Cells were isolated from the patient and from the healthy donor: functional assays were tested as already described (21). In brief, cells were cultured in triplicate, in 96 well round-bottom plates (Greiner, Nürtingen, FRG) in the presence of various combinations of stimuli. Bone marrow donor's PBL and unfractionated patient's PBL were plated at $60.10^{3}$ cells per well and sorted PBL at $20.10^{3}$ per well to test the proliferative responses and the possible suppressive function of sorted cells. The preparation of $\mathrm{T} 3$ beads and the proliferative response to this stimulus were performed as previously described (22). Each value represents the mean of triplicate cultures.

\section{Phenotypic analysis}

They were performed on a cytofluograph (Ortho Diagnostic Systems, Westwood, MA) after indirect immunofluorescence assays as previously described (21). Negative control was the irrelevant NS1 ascites. MAbs used to phenotype were Leu 4, Leu 7 (Becton Dickinson, Monoclonal Center, Mountain View, CA), T4, T8, and T6 kindly provided by E. Reinherz (Dana Farber Cancer Institute, Boston, MA). WT31 MAb was provided by J.E. Devries (Unicet Laboratories, Dardilly, France).

\section{Cell sorting experiments}

To purify WT31+ or WT31- cells from PBL or from cell lines, cells were stained by indirect immunofluorescence using WT31 ascites at a dilution of $1: 150$, plus FITC conjugated goat antimouse $F\left(a b^{\prime}\right)_{2}$ immunoglobulin (Tago, Inc., Burlingame, CA). The optimum dilution of WT31 MAb was previously determined. The results indicated that the plateau of maximum labeling was from 1:100 to 1:500 MAb dilution. WT31 + and WT31 - cells were sorted (Ortho, cytofluorograph) and collected in RPMI 1640 medium containing 10\% normal human serum, washed twice and resuspended in fresh medium for functional assays or for expansion in cell lines. Trypan blue dye exclusion was performed on both sorted population and vialibility was always $>90 \%$ in each fraction. To obtain CD3+ sorted cells, similar methods were employed using Leu 4 antibody.

\section{$T$ cell lines}

$1.10^{6}$ PBL were plated in $\mathrm{V}$ bottom 96 well plates with three fresh irradiated (3,000 rad) allogeneic donor cells $\left(6.10^{6}\right.$ per plate) as feeder layers in RPMI containing $10 \%$ of IL-2 conditioned medium prepared as described previously (21), $10 \%$ human serum and $1 \mu \mathrm{g} / \mathrm{ml}$ PHA. Cultures were fed every $3 \mathrm{~d}$ with conditioned medium and human serum. The cells were restimulated every $10 \mathrm{~d}$ in the presence of PHA, IL-2, and allogeneic feeder layers.

\section{Northern blot analysis}

Total cellular RNA was prepared by resuspending the cells in $4 \mathrm{M}$ guanidine, thiocyanate, subjecting them to disruption with a polytron homogenizer (Brinkmann Instruments, Inc., Westbury, NY) and pelleting them through $5.7 \mathrm{M} \mathrm{Cs} \mathrm{Cl}_{2}$ pad (23). RNA was electrophoresed in $7 \%$ formaldehyde, $1 \%$ agarose gels, blotted to nitrocellulose filters, and hybridized to ${ }^{32} \mathrm{P}$ labeled DNA probes as described (24). The Tc $\alpha$ probe was a 350-bp long fragment encompassing most of the constant region, the transmembrane encoding domain and some of the $3^{\prime}$ flanking sequence and was isolated from the PGA 5 cDNA clone (kindly provided by E. Palmer, National Jewish Hospital, Denver, $\mathrm{CO}$ ). The Tc $\beta$ probe was a 391 -bp long Xho2 genomic fragment representing part of the $C \beta$ encoding sequence. The Tc $\gamma$ probe was a

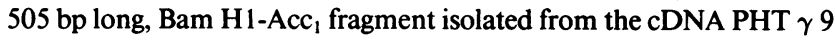
(provided by J. L. Strominger).

\section{Biochemical characterization of the CD3- associated molecules}

Antibodies. The rabbit anti-serum against the $\alpha$-subunit of the human $\mathrm{T}$ cell receptor, termed $\mathrm{H} 36$, was prepared by $\mathrm{M}$. Fabbi as described (25). W6.32 $\left(\operatorname{IgG}_{2 \mathrm{a}}\right)$ is a mouse monoclonal antibody which recognizes a common antigenic determinant of HLA-A, B, C antigens. UCH-T1 (IgG1) is an anti-CD3 monoclonal antibody with potent mitogenic properties (26). Rabbit anti-serum against the $\gamma$-subunit of the human TCR was a generous gift of T. Hercend (Institut Gustave Roussy, Villejuif) and was prepared as described (8). Rabbit antibodies against mouse immunoglobulin were purified by affinity chromatography on mouse IgG coupled to Affi-gel 10 (Bio-Rad Laboratories, Richmond, CA).

Radiolabeling. Cell surface proteins were labeled by lactoperoxidase-catalyzed-iodination (27).

Immunoprecipitation. Cells were lysed $\left(2 \times 10^{7}\right.$ cells $\left./ \mathrm{ml}\right)$ by standing for $15-30 \mathrm{~min}$. at $0^{\circ} \mathrm{C}$ in lysis buffer (triethanolamine $10 \mathrm{mM} \mathrm{pH}$ 7.8, containing $0.15 \mathrm{M} \mathrm{NaCl}, 1 \mathrm{mM}$ EDTA, $1 \%$ Digitonin (Serva Biochemica, Heidelberg, FRG), $1 \mathrm{mg} / \mathrm{ml} \mathrm{BSA}$ and $2 \mathrm{mM}$ PMSF plus $20 \mathrm{mM}$ iodoacetamide as protease inhibitors. Nuclei were removed by centrifugation for $10 \mathrm{~min}$ at $2,000 \mathrm{~g}$ and the supernatant was centrifuged at $100,000 \mathrm{~g}$ for $30 \mathrm{~min}$. at $4^{\circ} \mathrm{C}$. Then lysates were filtered through Sephadex G-25 (PD-10 columns from Pharmacia) equilibrated with lysis buffer containing only $0.1 \%$ digitonin to remove dialyzable radioactive material. Cell lysates were immunoprecipitated by monoclonal antibodies using affinity purified rabbit anti-mouse Ig coupled to protein A Sepharose. These antibodies were coupled to protein A Sepharose by using dimethylpimelimidate $\mathrm{HCl}$ as described (28).

Diagonal gel electrophoresis. (First dimension SDS PAGE nonreducing, second dimension SDS PAGE reducing). NP40 lysates were boiled for $5 \mathrm{~min}$ in sample buffer, applied to a $7.5 \%$ polyacrylamide gel and run under nonreducing conditions. A band of gel in which polypeptides of molecular weights ranging from 75 to $100 \mathrm{kD}$ were included, was cut and incubated in sample buffer containing 5\% beta mercaptoethanol and $0.1 \mathrm{M}$ DTT for $30 \mathrm{~min}$ at room temperature. This band was electrophoresed on a 10 to $13 \%$ slab gel. After electrophoresis followed by autoradiography at $-80^{\circ} \mathrm{C}$, the spots corresponding to the chains of the TCRs were eluted.

Electrophoresis analyses. Polyacrylamide slab gels were electrophoresed in the SDS buffer of Maizel and Laemmli, as described (29). The gels were run, fixed, and dried as previously described. Samples for electrophoresis were dissolved in $2 \%$ (vol/vol) SDS, $10 \%$ (vol/vol) glyc- 
Table I. Phenotypic Analysis of Patient PBL after BMT

\begin{tabular}{ccccccr}
\hline & \multicolumn{7}{c}{ \% Positive for } \\
\cline { 2 - 7 } Months after BMT & CD2 & CD3 & Ti(WT31) & CD4 & CD8 & CD1 \\
\hline 3 & 75 & 37 & 35 & 17 & 37 & NT \\
6 & 78 & 70 & 29 & 5 & 28 & 0 \\
12 & 76 & 75 & 25 & 4 & 23 & 0
\end{tabular}

erol, $80 \mathrm{mM}$ Tris- $\mathrm{HCl}, \mathrm{pH} 6.8,0.1 \mathrm{M}$ DTT, and $0.02 \%$ bromophenol blue (SDS sample buffer) and heated at $100^{\circ} \mathrm{C}$ for $3 \mathrm{~min}$ before layering onto the gel. Autoradiography of dried slab gels was performed at $-70^{\circ} \mathrm{C}$ with Kodak X-Omat $\mathrm{H}-\mathrm{x}$ - ray film and Dupont intensifying screens (Quanta III). Molecular weights were calculated by reference to the mobilities of the standard proteins.

\section{Results}

Phenotypic analysis of PBL. In patient PBL, at least $40 \%$ of CD3+ lymphocytes expressed neither CD4 nor CD8 cell surface antigens, $6 \mathrm{mo}$ after grafting. The lack of expression of these $T$ cell differentiation antigens led us to investigate the presence of surface $\alpha: \beta$ heterodimer on PBL using WT31 MAb. One color fluorescence of PBL indicated that $70 \%$ of cells were CD3+ and only $29 \%$ WT $31+$.

The percentage of WT $31+$ lymphocytes remained identical whatever the dilution of WT31 MAb used (1:100 to 1:500). Phenotypic analysis of sorted PBL showed that in the WT31cells, $60 \%$ were CD3+, $80 \%$ CD2+ and $38 \%$ dim CD8+ (data not shown). In the CD3+ sorted population, only $40 \%$ cells were WT $31+$. Thus $60 \%$ of circulating b́lood CD3+ lymphocytes were WT31-: No discrepancy between the percentage of CD3+ and WT31+ lymphocytes was observed 3 mo postgrafting. This CD3+ WT31- subset of circulating PBL appeared between 3 and $6 \mathrm{mo}$ and remained stable $1 \mathrm{yr}$ after BMT (Table I).

Analysis of $\alpha, \beta$, and $\gamma$ chain transcripts. To determine why the majority of patient CD3+ lymphocytes failed to react with WT31 MAb, we analyzed homogeneous cell lines for messen-

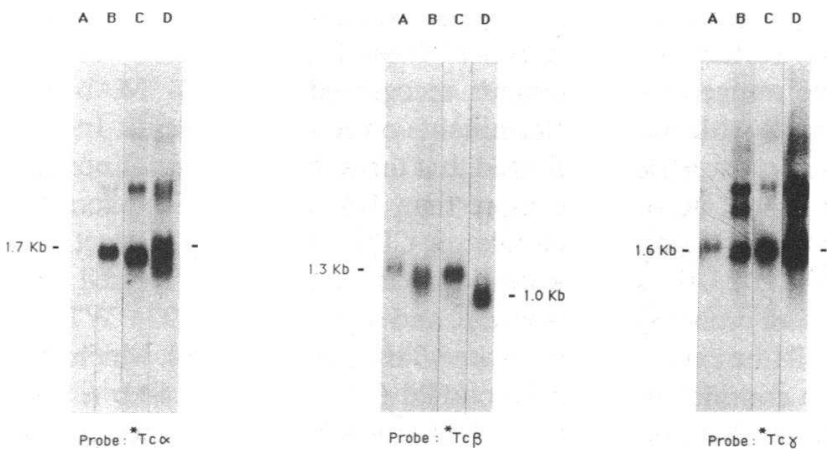

Figure 1. Northern blot analysis using ${ }^{*} \mathrm{Tc} \alpha,{ }^{*} \mathrm{Tc} \beta$, and ${ }^{*} \mathrm{Tc} \gamma$ probes. RNA was isolated from KE37, a WT31-thymic leukemia cell line (lane $A$ for each probe); this KE37 cell line is known to express $\beta$ and $\gamma$ transcript but no $\alpha$ mRNA (16). RNA was isolated from ABo, a WT31 + T cell clone established from a normal donor (lane $B$ for each probe), from patient CD3+WT31+ cell line (lane $C$ for each probe) and from patient CD3+ WT 31 -cell line (lane $D$ for each probe).

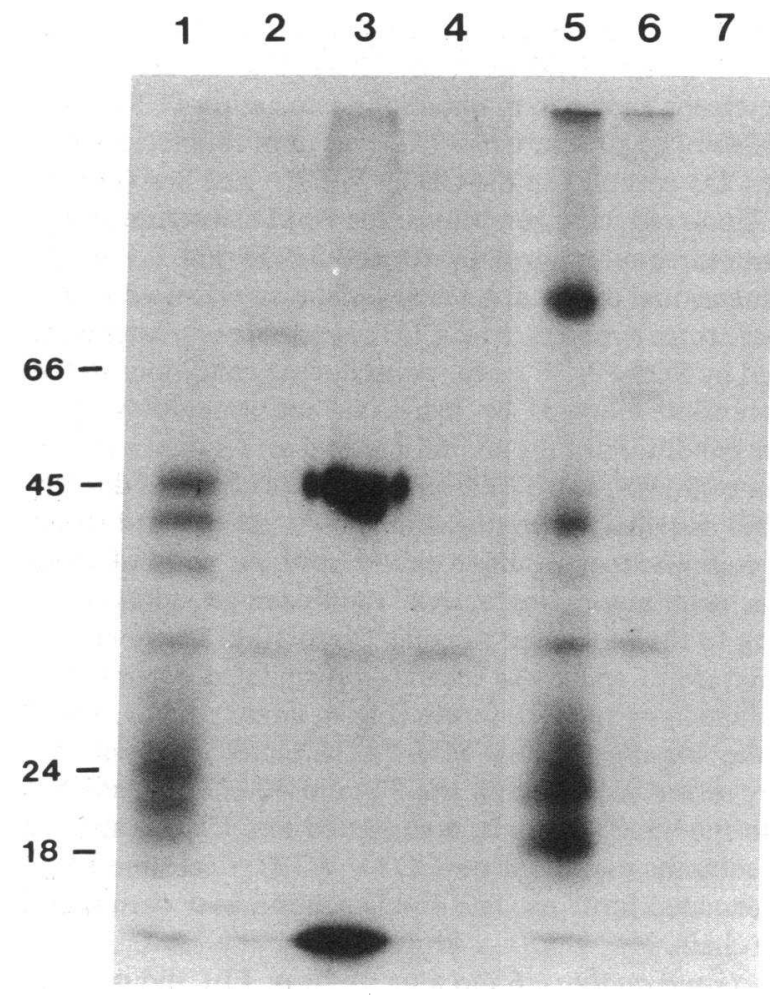

Figure 2. SDS-PAGE analysis of immunoprecipitates from CD3+ WT 31 - cells. Surface radioiodinated cell line was lysed in buffer containing digitonin. These lysates were immunoprecipitated by anti-CD3 monoclonal antibody (lanes I and 5), rabbit anti-Ti $\alpha$ serum (lanes 2 and 6), anti-MHC class I monoclonal antibody (lane 3 and a rabbit antibody against mouse immunoglobulin (lanes 4 and 7). These immunoprecipitates were analyzed on a $13 \%$ SDS-PAGE in reducing (lanes 1-4) or in nonreducing conditions (länes 5-7).

ger RNAs encoding TCR $\alpha$ and $\beta$ chains by Northern blotting. To obtain phenotypically homogenous cell lines, the following procedures were carried out: $\mathrm{CD} 3+$ sorted PBL were expanded to obtain cell lines that were $100 \% \mathrm{CD} 3+$ and $30 \%$ WT31+. Subsequent sorting of these cell lines, using WT31 MAb yielded a homogeneous population of CD3+ WT31- cells $(<5 \%$ contamination of WT31 + cells) and CD3+ WT31+ cells.

The CD3+ WT31- cell line was CD4 negative 30\% CD8 dim-positive and the cytogenetic analysis confirmed that these cells originated from the male donor.

As expected, the CD3+WT31+ cell line (Fig. 1, lane $C$ ), expressed a 1.3-kb $\beta$ transcript, and a 1.7-kb $\alpha$ transcript. In contrast the CD3 + WT31 - cell line (Fig. 1, lane $D$ ) expressed only a truncated $1.0-\mathrm{kb} \beta$ transcript, indicating a nonfunctional $\beta$ mRNA (30). In addition the same line transcribed $\alpha$ mRNAs, the major band being a truncated 1.4-kb messenger different from the full length $1.7 \mathrm{~kb}$ mRNA. The same Northern blots were rehybridized using the Tc $\gamma$ probes. When compared with the CD3+ WT $31+$ cells, higher levels of $1.6 \mathrm{~kb}$ T $\gamma$ mRNA were detected in the CD3+ WT31- cells.

Biochemical characterization of the CD3 associated structures in the CD3+WT31-cell line. To demonstrate that these cells bear a TCR $\gamma$ protein noncovalently associated with CD3 
complex on their cell surfaces, the ${ }^{125} I$ labeled lysates were reacted with an anti-CD3 antibody UCHTl, using the digitonin, a detergent known to maintain the association TCR-CD3. A disulfide linked structure of $90 \mathrm{kD}$ was immunoprecipitated with the CD3 complex in the CD3+ WT31- cell line (Fig. 2, lane 5). Upon reducing conditions, the $90 \mathrm{kD}$ structure dissociated into three subunits of 45,40 , and $37 \mathrm{kD}$ (Fig. 2, lane 1). Two-dimensional diagonal gel electrophoresis was used to analyze these three subunits. Anti CD3 immunoprecipitates were separated by SDS-PAGE under nonreducing conditions in the first dimension followed by reduction and separation upon reducing conditions in the second dimension. As shown in Fig. 3 , all three 45-, 40-, and 37-kD subunits were observed directly below the diagonal suggesting that the $90-\mathrm{kD}$ reduced structure is composed of disulfide linked dimeric pairs of these subunits. After autoradiography of the frozen gel, spots corresponding to the molecular range of 30 to $50 \mathrm{kD}$ were eluted. This mixture of spots was immunoprecipitated by anti-T $\gamma$ (Fig. 4, lane 2) or anti-T $\alpha$ serum (Fig. 4, lane 3). Fig. 4, lane 1 shows the two-dimensional SDS-PAGE eluted material. As anti-C $\dot{\gamma}$ serum reacted with the $37-$ and $40-\mathrm{kD}$ subunits but not with the 45-kD subunit, it suggested that the 37- and the 40-kD subunits expressed on CD3+ WT31- cell line are $\gamma$ chains encoded proteins. The $45-\mathrm{kD}$ subunit may correspond to the $\delta$ chain.

Functional analysis. 6 mo after grafting, PBL did not proliferate either to PHA or to allogeneic cells and showed a depressed response to $\mathrm{T} 3$ beads. Cell sorting experiments were performed using WT31 MAb or anti CD3 MAb to study the proliferative response of purified subsets of $\mathrm{PBL}$. The CD3+ or the WT $31+$ sorted cells were tested after the addition of $5 \%$ autologous adherent cells. Unseparated PBL as the CD3+ sorted cells did not respond to mitogen and allogeneic cells and the response to $\mathrm{T} 3$ beads was impaired. On the contrary, the WT31+ patient PBL like donor PBL, exhibited a positive response to the stimuli tested. This significant difference between the response of WT31+ and the unfractionated patient PBL cannot be due to the number of WT $31+$ cells present in each proliferative assay since they were roughly the same. These combined data rule out the possibility that PBL unresponsiveness is totally due to CD3- cells.

The WT31- sorted patient PBL showed a depressed response to T3 beads compared to WT31+ sorted PBL and no reactivity was found to PHA and allogeneic cells. To test the inhibitory effect of the WT31- circulating population, we

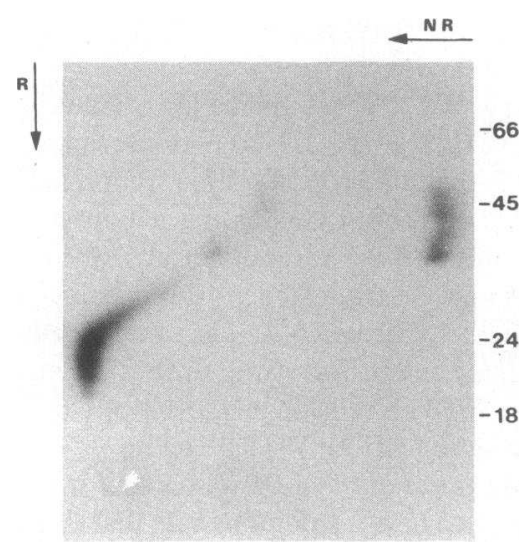

Figure 3. Two-dimensional SDS-PAGE (reduced vs. nonreduced) analysis of an anti-CD3 immunoprecipitates from the CD3+ WT31 - cell lysates.

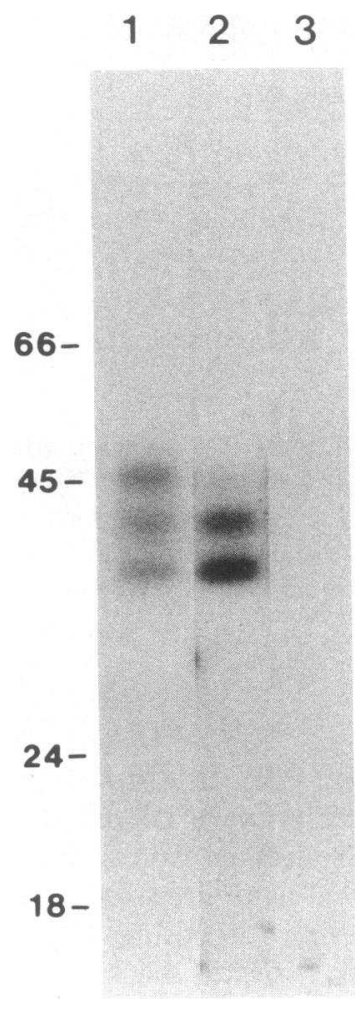

Figure 4. SDS-PAGE analysis of the two-dimensional gel eluted spots corresponding to the molecular range of $30-50 \mathrm{kD}$. The mixture of spots was immunoprecipitated by anti-T $\gamma$ serum (lane 2) or anti-Ti $\alpha$ serum (lane 3) and analyzed in parallel with the whole eluate (lane 1 ) on $13 \%$ SDS-PAGE in reducing conditions.

used the bone marrow donor cells, actually genotypically identical to the patient cells; the patient having been reconstituted with the donor cells.

Each sorted patient PBL, using WT31 MAb, were added to the donor cells activated with CD3 beads. As indicated in Table II, only the WT31 - sorted patient cells were able to inhibit the proliferative response of donor cells, induced by $\mathrm{T} 3$ beads (donor cells and WT31+ cells: $8632 \mathrm{cpm}$, versus donor cells and WT31- cells: $730 \mathrm{cpm}$ ).

\section{Discussion}

In the patient with sustained immunodeficiency after BMT, the majority of the CD3+ PBL was shown not to express the cell surface $\alpha: \beta$ heterodimer. These CD3+ cells did not bear the antigenic determinants recognized by WT31 MAb that reacts with shared determinants on $\alpha$ and $\beta$ subunits. In normal controls, we confirmed that this subset remains minor and does not account for more than $10 \%$ of PBL. To determine why the majority of circulating $\mathrm{CD} 3+$ cells failed to react with WT31 MAb, gene expression was examined on the cell lines using probes specific for $\alpha, \beta$, and $\gamma$ genes. The CD3+ WT31cell line expressed a truncated $\beta$ transcript $(1.0 \mathrm{~kb})$, which may be considered as nonfunctional (30). A short 1.4-kb $\alpha$ transcript, but not a mature 1.7-kb mRNA, was also detected. It is worth noting that no functional $\alpha$ chain transcript is generally detected in T cells bearing $\gamma$ chains. Nevertheless, short $1.4 \mathrm{~kb}$ $\alpha$ transcripts were found in the early stage of thymocyte development in the mouse (31) and it has been demonstrated that the CD4-CD8- thymocytes expressing a 1.4-kb $\alpha$ transcript bear $\gamma$ chains on their cell surface (2). By analogy with the $\beta$ gene, this shorter transcript is probably nonfunctional and 
Table II. Functional Analysis of Patient PBL before and after Sorting with WT31 and Anti-CD3 Stimulus

\begin{tabular}{lrrrrr}
\hline \multicolumn{1}{c}{ PBL } & Medium & PHA & T3 Beads & $\begin{array}{c}\text { Allogeneic unrelated cells } \\
\text { (MLR) }\end{array}$ & $\begin{array}{c}\text { Conditioned } \\
\text { medium + PHA }\end{array}$ \\
\hline Donor cells & 135 & 15,320 & 7,850 & 5,430 & 59,950 \\
Unfractionated patient cells & 50 & 150 & 1,237 & 150 & 12,985 \\
WT31+ sorted patient cells & 40 & 4,220 & 5,491 & 1,283 & 45 \\
WT31- sorted patient cells & 20 & 30 & 620 & 210 & 8,175 \\
CD3+ sorted patient cells & 105 & 390 & 930 & ND & ND \\
Donor cells and WT31 + sorted patient cells & 150 & ND & 8,632 & 726 \\
Donor cells and WT31 - sorted patient cells & 112 & ND & 730 & ND & ND \\
& & & & &
\end{tabular}

These results are expressed in incorporation of $\left[{ }^{3} \mathrm{H}\right]$ thymidine, $\mathrm{cpm}$.

may result from either partial rearrangement or aberrant transcript of a germline gene (31).

To further investigate the CD3-associated molecules, sequential immunoprecipitations were conducted using anti$\mathrm{CD} 3$ antibodies and hetero antiserum anti-C $\gamma$ raised against synthetic $\gamma$ chain peptide. We have shown that the CD3+ WT31- cell line expressed disulfide linked dimeric pairs of $\gamma$ chains, 37 and $40 \mathrm{kD}$ and a non- $\gamma$ product, $45 \mathrm{kD}$ termed $\delta$. As other authors (6) we have demonstrated that both $\gamma$ subunits are expressed on the same cells (32), using $T$ cell clones. Further studies are required to determine whether these three subunits are associated on the cell surface as $\gamma: \gamma$ homodimers, or $\gamma ; \delta$ heterodimers. It is interesting to note that TCR $\gamma: \delta$ bearing cells isolated from pathological samples, immunodeficient $T$ cell lines (3) or PEER T cell line (4) expressed a nondisulfide linked heterodimer, whereas the TCR $\gamma: \delta$ cells of our patient expressed disulfide-linked dimers, as the subset isolated from normal controls. Actually, this difference in the TCR gamma structure reflects the preferential use of two different $\mathrm{C}_{\gamma}$ genes $(33,34)$.

Finally, we showed that this patient predominantly expressed a population of TCR $\gamma: \delta$ bearing cells in peripheral blood. This subset, which represents $40 \%$ of PBL was observed during the entire 12-mo followup. Although double labeling with monoclonal antibodies against CD8, CD4 or WT31 was not performed, our results indicate that the majority of circulating TCR $\gamma: \delta$ cells was double negative CD4-CD8-. Nevertheless the phenotypic analysis of WT31- sorted PBL was consistent with a minor fraction of TCR $\gamma: \delta$ cells expressing low levels of CD8 antigens.

The major expression of circulating TCR $\gamma: \delta$ cells was associated with a severe immunodeficiency characterized by lymphocytosis, a profound decrease of CD4+ cells and the absence of proliferative response to mitogens and antigens. Even though the TCR $\gamma: \delta$ cells have been described in patients with constitutional immunodeficiency, using CD3+ WT31cell lines, no results indicating such a large population circulating in the peripheral blood have so far been reported. This first report of such an immunodeficiency is described in a recipient having received a $T$ cell-depleted, HLA matched BMT. Generally such grafted patients have subtle and measurable abnormalities in $\mathrm{T}$ cell immunity for up to 2-3 yr posttransplant, but sufficient immunological restoration with a significant proliferative response to mitogens is more often achieved within the 6 mo postgrafting to limit the risk of the late occurrence of opportunistic infections, especially when the patient does not develop GVHD $(15,35)$. In this respect, CMV infection is known not to hinder the immune reconstitution after grafting $(18,19)$. Even if this virus may have some immunosuppressive effects it does not explain the PBL unresponsiveness to any stimuli (36) that is the cause but not the consequence of CMV infection.

Our observations raised questions regarding the relationship between the in vivo expansion of TCR $\gamma: \delta$ cells and the severe immunodeficient state observed in this patient. AntiCD3 MAb coupled to Sepharose beads, which crosslinks the CD3-TCR complex, induces IL-2 receptor and IL-2 secretion in normal PBL as the donor cells. It is worth noting that the WT31 - cells did not proliferate in response to anti-CD3 beads. We have shown using $\mathrm{T}$ cell $\gamma: \delta$ bearing clones derived from patient PBL that the proliferation required exogeneous recombinant IL2 (32) as it has been described in mouse TCR $\gamma: \delta$ thymocytes (13). To study the possible relationship between the immunodeficient state and the emergence of the circulating TCR $\gamma: \delta$ cells, functional analyses were performed using sorted PBL with anti CD3 or WT31 MAb. The ability of CD3+ WT31+ sorted cells to proliferate, coupled with the failure to respond of unseparated PBL, addresses the issue of the role of WT31- cells in the unresponsiveness of PBL. The ability of WT31 - cells to suppress T3 beads' proliferative response of the bone marrow donor cells suggests that the WT31- cells may exert a suppressor activity. It is interesting to note that these WT31- sorted cells included a majority of CD3 + WT31 - cells but also macrophages and CD3- CD2+ cells and we have to determine which subset may be responsible for the unresponsiveness of PBL. The addition of macrophages to WT31+ cells did not alter their proliferative response either to PHA, T3 beads, or allogeneic cells. The CD3+ sorted PBL exhibited the same unresponsiveness as unfractionated PBL. Taken together these data suggest that within the circulating WT31- cells, the CD3+WT31- cell subset, may mediate an inhibitory function. Moreover, we have analyzed the possible mechanism of this suppression using TCR $\gamma: \delta$ bearing cell lines, since we have shown that these cells exert a MHC unrestricted cytotoxicity against a large range of different activated targets including autologous cells (manuscript in preparation).

However this functional role cannot yet be generalized to functions of minor TCR $\gamma: \delta$ subset normally residing in peripheral blood since the patient TCR $\gamma: \delta$ cells presented some 
distinct characteristics similar to immature T cells. As murine fetal TCR $\gamma: \delta$ thymocytes, they expressed a short $\alpha$ transcript and they are unable to proliferate when triggered with antiCD3 beads $(2,13)$. It may be possible that the thymus which generates the selection process of $\mathrm{T}$ cells was impaired after BMT, by several factors, including total irradiation, chemotherapy, viral infections, cyclosporine A. An ineffective elimination mechanism due to this impaired thymus might explain that the pool of TCR $\gamma: \delta$ thymocytes tends to increase and leave the thymus. Alternatively, the expansion of immature $T$ cells may be explained by a preferential extrathymic pathway of differentiation after grafting since it has been demonstrated that young athymic mice expressed predominantly TCR $\gamma: \delta$ cells in periphery (37).

\section{Acknowledgments}

The authors wish to thank the staff of the bone marrow transplant unit, R. Miglierina for assistance in cell sorting experiments. M. Prendergast for her technical assistance, F. Varrin for help to carry out the T cell depletion of the bone marrow donor, and J. Vignau for the preparation of the manuscript. In addition, we would like to thank J. E. Devries for providing WT31 MAb and T. Hercend for the Tc $\alpha$ serum.

This work was supported in part by ARC grant 64-59, Fondation contre la Leucémie and INSERM.

Note added in proof. We have recently shown that this circulating TCR $\gamma: \delta$ subset preferentially expresses a functional variable (V) segment of $\gamma$ gene $(\mathrm{V} \gamma 5$ ). Moreover, we have demonstrated that the $\mathrm{V}$ region used by the $\delta$ gene in this population is a member of a $V \gamma 6$ gene family.

\section{References}

1. Nowill, A., P. Moingeon, A. Ythier, M. Graziani, F. Faure, L. Delmon, M. Rainaut, F. Forestier, C. Bohuon, and T. Hercend. 1986. Natural killer clones derived from fetal (25wk) blood. Probing the human T cell receptor with WT31 monoclonal antibody. J. Exp. Med. 163:1601-1606.

2. Bank, I., R. A. Depinho, M. B. Brenner, J. Cassimeris, F. W. Walt, and L. Chess. 1986. A functional T3 molecule associated with a novel heterodimer on the surface of immature human thymocytes. Nature (Lond.). 322:179-181:

3. Brenner, M. B., J. McLean, D. P. Dyalynas, J. L. Strominger, J. A. Smith, F. L. Owen, J. G. Seidman, S. Ip, F. Rosen, and M. S. Krangel. 1986. Identification of putative second T cell receptor. $\mathrm{Na}$ ture (Lond.). 322:145-149.

4. Weiss, A., M. Newton, and D. Crommie. 1986. Expression of T3 in association with a molecule distinct from the $\mathrm{T}$ cell antigen receptor heterodimer. Proc. Natl. Acad. Sci. USA. 83:6998-7002.

5. Moingeon, P., A. Ythier, G. Goubin, F. Faure, A. Nowill, L. Delmon, M. Rainaud, F. Forestier, F. Daffos, C. Bohuon, and T. Hercend. 1986. A unique T cell receptor complex expressed on human fetal lymphocytes displaying natural killer like activity. Nature (Lond.). 323:638-640.

6. Borst, J., R. J. Van de Griend, J. W. Van Oostveen, S. E. Ang, C. J. Melief, J. G. Seidman, and R. L. H. Bolhuis. 1987. A T-cell receptor $\gamma / \mathrm{CD} 3$ complex found in cloned functional lymphocytes. Nature (Lond.). 325:683-688.

7. Brenner, M. B., J. McLean, H. Scheft, J. Riberdy, S. L. Ang, J. G. Seidman, P. Devlin, and M. Krangel. 1987. Two forms of the T-cell receptor $\gamma$ protein found on peripheral blood cytotoxic $T$ lymphocytes. Nature (Lond.). 325:689-694.

8. Moingeon, P., S. Jitsukawa, F. Faure, F. Troalen, F. Triebel, M. Graziani, F. Forestier, F. Bellet, D., C. Bohuon, and T. Hercend. 1987. A $\gamma$ chain complex forms a functional receptor on cloned human lymphocytes with natural killer like activity. Nature (Lond.). 325:723726.

9. Nakanishi, N., K. Maeda, K. I. Ito, M. Heller, and S. Tonegawa. 1987. $\mathrm{T} \gamma$ protein is expressed on murine fetal thymocytes as a disulphide-linked heterodimer. Nature (Lond.). 325:720-723.

10. Lanier, L. L., and A. Weiss. 1986. Presence of Ti (WT31) negative T lymphocytes in normal blood and thymus. Nature (Lond.). 324:268-270.

11. Chien, Y. M., M. Iwashima, K. B. Kaplan, J. F. Elliot, and M. M. Davis. 1987. A new T-cell receptor located within the alpha locus and expressed early in T-cell differentiation. Nature (Lond.). 327:677-682.

12. Pardoll, D. M., B. J. Fowlkes, J. A. Bluestone, A. Kruisbeek, W. L. Maloy, J. E. Coligan, and R. H. Schwartz. 1987. Differential expression of two distinct T-cell receptors during thymocyte development. Nature (Lond.). 326:79-81.

13. Bluestone, J. A., D. Pardoll, S. O. Sharrow, and B. J. Fowlkes. 1987. Characterization of murine thymocytes with CD3 associated T-cell receptor structures. Nature (Lond.). 326:82-84.

14. Lanier, L. L., N. A. Federspiel, J. J. Ruitenberg, J. H. Phillips, J. P. Allison, D. Littman, and A. Weiss. 1987. The T cell antigen receptor complex expressed on normal peripheral blood CD4-, CD8T lymphocytes. A CD3-associated disulfide linked $\gamma$ chain heterodimer. J. Exp. Med. 165:1076-1094.

15. Witherspoon, R. O., D. Matthews, R. Storb, K. Atkinson, M., Cheever, H. J. Deeg, K. Doney, J. Kalbfleisch, D. Noel, R. Prentice, K. M. Sullivan, and E. D. Thomas. 1984. Recovery of in vivo cellular immunity after human marrow grafting. Transplantation. 37:145151.

16. Spits, H., J. Borst, W. Tax, P. J. A. Capel, C. Terhost, and J. E. Devries. 1985. Characteristics of a monoclonal antibody (WT31) that recognizes a common epitope on a human $\mathrm{T}$ cell receptor for antigen. J. Immunol. 135:1922-1928.

17. Gluckman, E., A. Devergie, O. Poirier, and F. Lokiec. 1983. Use of cyclosporin A as prophylaxis of graft versus host disease after human allogeneic bone marrow transplantation. Transplant. Proc. 4:2628-2633.

18. Vilmer, E., M. C. Mazeron, C. Rabian, O. Azogui, A. Devergie, Y. Perol, and E. Gluckman. 1985. Clinical significance of cytomegalovirus viremia in bone marrow transplantation. Transpilantation. 40:30-34.

19. Kernan, N. A., N. H. Collins, J. Juliano, T. Cartagena, B. Dupont, and R. J. O'Reilly. 1986. Clonable T lymphocytes in T cell depleted bone marrow transplants correlate with development of graft host disease. Blood. 68:770-774.

20. Collaborative DHPG treatment study group. 1986. Treatment of serious cytomegalovirus infections with 9-(1,3 dihydroxy-2-propoxymethyl) guanine in patients with AIDS and other immunodeficiencies. N. Engl. J. Med. 314:801-805.

21. Bensussan, A., B. Tourvieille, L. K. Chen, J. Dausset, and M. Sasportes. 1985. Phorbol ester induced a differential effect on the effector function of human allospecific CTL and NK clones. Proc. Natl. Acad. Sci. USA. 82:6642-6646.

22. Meuer, S. C., J. C. Hodgdon, R. E. Hussey, J. P. Protentis, S. F. Schlossman, and E. L. Reinherz. 1983. Antigen like effects of monoclonal antibodies directed at receptors on human T cell clones. J. Exp. Med. 158:988-992.

23. Chirgwin, J. M., A. E. Przybyla, R. S. McDonald, and W. S. Rutter. 1979. Isolation of biologically active ribonucleic acid from sources enriched in ribonuclease. Biochemistry. 18:5294-5299.

24. Thomas, P. S. 1980. Hybridization of denatured RNA and small DNA fragments transferred to nitrocellulose. Proc. Natl. Acad. Sci. USA. 77:5201-5206.

25. Fabbi, M., O. Acuto, A. Bensussan, C. B. Poole, and E. L. Reinherz. 1985. Production and characterization of antibody probes directed at constant regions of the $\alpha$ and $\beta$ subunits of the human T-cell receptor. Euir. J. Immunol. 15:821-827. 
26. Beverley, P. C. L., and R. E. Callard. 1981. Distinctive functional characteristics of human $\mathrm{T}$ lymphocytes defined by $\mathrm{E}$ rosetting or a monoclonal anti-T cell antibody. Eur. J. Immunol. 11:329-334.

27. Hubbard, A. L., and Z. A. Cohn. Specific labels for cell surfaces. 1976. In Biochemical Analysis of Membranes. A. H. Maddy, editor. Chapman and Hall, London. 427-501.

28. Schneider, C., R. A. Newman, R. D. Sutherland, U. Asser, and M. F. Greaves. 1982. A one-step purification of membrane proteins using a high efficiency immuno-matrix. J. Biol. Chem. 257:1076610769.

29. Ames, G. F. L. 1974. Resolution of bacterial proteins by gel electrophoresis on slabs. J. Biol. Chem. 249:634-639.

30. Yasunobu, Y., D. Anatomiou, S. P. Clark, Y. Yanagi, R. Sangster, P. V. den Elsen, C. Terhost, and W. Tax. 1984. Sequence and expression of transcripts of the human $\mathrm{T}$ cell receptor $\beta$ chain genes. Nature (Lond.). 312:521-524.

31. Kronenberg, M., G. Siu, L. E. Hood, and N. Shastri. 1986. The molecular genetics of the $\mathrm{T}$-cell antigen receptor and $\mathrm{T}$-cell antigen recognition. Annu. Rev. Immunol. 4:529-591.

32. David, V., G. Leca, E. Vilmer, P. Guglielmi, S. Chouaib, J. Kanellopoulos, F. Sigaux, and A. Bensussan. 1988. Expression of the T cell gamma gene by a functionally defined human T cell clone: characterization at DNA, RNA and cell membrane level. Scand. J. Immunol. In press.

33. Littman, D. R., M. Newton, D. Crommie, S. L. Ang, J. G. Seidman, S. N. Gettner, and A. Weiss. 1987. Characterization of an expressed $\mathrm{CD} 3$ associated $\mathrm{Ti} \gamma$ chain reveals $\mathrm{C} \gamma$ domain polymorphism. Nature (Lond.). 326:85-88.

34. Lefranc, M. P., A. Forster, and T. H. Rabbits. 1986. Genetic polymorphism and exon changes of human $\mathrm{T}$ cell rearranging constant region genes. Proc. Natl. Acad. Sci. USA. 83:9596-9600.

35. Rozans, M. K., B. R. Smith, S. J. Burakoff, and R. A. Miller. 1986. Long lasting deficit of functional $T$ cell precursors in human bone marrow transplant recipients revealed by limiting dilution methods. J. Immunol. 136:4040-4048.

36. Ljungman, P., B. Lönnqvist, B. Wahren, O. Ringden, and G. Gahrton. 1985. Lymphocyte responses after cytomegalovirus infection in bone marrow transplant recipients. A one year follow up. Transplantation. 40:515-520.

37. Yoshikai, Y., M. D. Reis, and T. W. Mak. 1986. Athymic mice express a high level of functional $\gamma$ chain but greatly reduced levels of $\alpha$ and $\beta$ chains T cell receptor messages. Nature (Lond.). 324:482-485. 